\title{
Atypical Forms of Employment on Hungarian- Slovakian Border Areas in Light of Empirical Researches
}

\author{
Jozsef Poor ${ }^{1}$, Szergej Vinogradov ${ }^{2}$, Györgyi Gábrielné Tőzsér ${ }^{3}$, \\ Imrich Antalik ${ }^{4}$, Zsolt Horbulák ${ }^{5}$, Tímea Juhász ${ }^{6}$, Ildikó Éva \\ Kovács ${ }^{7}$, Krisztina Némethy ${ }^{8}$, Renáta Machová9
}

1,4,9 J. Selye University, Faculty of Economics, Bratislaská cesta 3322, 94501

Komárno, Slovak Republik

2, 3,7 Szent István University, Páter Károly utca 1, 2100 Gödöllö, Hungary

${ }^{5}$ Alexander Dubček University, Študentská 2, 91150 Trenčín, Slovak Republik

${ }^{6}$ Hostlogic Co., Váci út 35, 1134 Budapest

${ }^{8}$ Óbuda University, University Research and Innovation Center, Bécsi út 96/b, 1034 Budapest

poor.jozsef@gtk.szie.hu, vinogradov.szergej@gtk.szie.hu, gabrielne.tozser.gyorgyi@gtk.szie.hu, antaliki@ujs.sk, zsolt.horbulak@tnuni.sk, tjuhasz@hostlogic.hu, kovacs.ildiko.eva@gtk.szie.hu,

nemethy.krisztina@rh.uni-obuda.hu,machovar@ujs.sk

Abstract: A survey was conducted to gain information about typical and atypical patterns of employment among unemployed, students of higher education and companies. The research was geographically restricted to the Slovak-Hungarian border region, to Komárom - Esztergom (Hungary), and Révkomárom (Komarno) - Párkány (Šturovo) (Slovakia) areas. A questionnaire survey was applied, which could be submitted in printed form or electronically. The research was actually a continuation of a previous study with a focus to find out how atypical forms of employment were able to reduce and influence unemployment.

Keywords: employment; atypical employment; youth employment; re-employment of the unemployed; corporate attitudes

\section{Introduction}

The workforce is more valuable and complex item than any other goods or services available on the market. It is not enough to hire employees, they have to be encouraged to work effectively and remain loyal to their employer. The employee does not only work for a living, but also appreciates the work, prestige, 
and pays attention to other factors, e.g. company image, corporate culture and many other internal and external factors. The form of employment itself can be an important factor. Nowadays, there is an increase of non-traditional forms of employment; however, they are still regarded as atypical forms of employment. On the basis of foreign and partly domestic experience atypical patterns of employment can provide more comfortable and personalised working conditions for the employee, but they may bring some benefits to the employer as well.

The reason why non-standard forms of employment have not spread in the Central and Eastern European region is, that these forms of employment are still regarded as alternative opportunities to reduce unemployment. Our research focused on the Slovak-Hungarian border area, Komárom and Esztergom, resp. Révkomárom (Komarno) and Párkány (Štúrovo), more precisely Komárom-Esztergom county and district of Komárom and Érsekújvár (Nové Zamky). Four universities of two countries, a number of local labour offices and other institutions joined the research.

Our objective was to examine the attitude of companies, employees, generation $\mathrm{Y}$ and the future employees of generation $\mathrm{Z}$ towards atypical forms of employment (atypical, non-standard and cross-border employment). The surveyed issue was approached from two different perspectives. Our first assumption was that the age and qualification of employees determine their attitude towards atypical forms of employment. We can assume that respondents of generation $\mathrm{Y}$ and $\mathrm{Z}$ show more willingness to accept atypical employment patterns. We can say that young job seekers are less likely to weaken the perspectives of atypical employment patterns than the older generation. At the same time, public employment has the lowest preference among young (future) employees.

\section{Typical and Atypical Employment}

The issue of atypical employment has already been in the focus of economists for three decades. Since the last quarter of the $20^{\text {th }}$ Century, we can find several contributions in scientific literature. Efren Córdova (1986) from ILO is one of the pioneers, who studied the emergence of atypical employment patterns at a global level. According to him, the non-standard patterns of employment were widespread, when he published her article. The attitude towards atypical employment patterns was different. Some observe regarded them as a threat to the survival of the principles that have shaped the labour law; others were worrying about the disappearance of classical system of workforce protection, which would lead to reorganization of employment relationships and increasing anomalies that may undermine the effectiveness of traditional system of the employment relationship. According to Córdova, it would be unwise to declare that all forms of atypical employment are said to be insecure but it does not mean that there are no problems. Atypical employment is characterised by a total or partial absence of regulations that could increase the vulnerability and instability of workers. 
The increasing tendency of atypical employment patterns in the United States was analysed by Moberly (1987). Firms, offering temporary employment existed in the USA in the 1920s, but the boom in the industry started immediately after World War II and continues up to now. Moberly describes the legal background quite differently. Most of the workers, who have atypical work arrangement, are protected by collective bargaining agreements.

The atypical forms of employment in the European Union became so general in the last decade of the $20^{\text {th }}$ Century that would be enough to analyse only two types of them. De Grip, Hoevenberg and Willems in 1997 dealt with the most widespread forms; the part-time and temporary employment relations. Their article provides a summary based on a survey of Eurostat about the member states of the EU. Interesting and comprehensive data about the situation in EU member countries between years 1996-2011 was published by the Research Centre for Social Sciences - Sozialforschung (Allmendinger, Hipp and Stuth, 2013). A review about the atypical employment patterns in Central and Eastern European region was completed by Lipták (2011). The research of Oliveira, Carvalho and Veloso (2011) focuses on young people (aged 15-24).

The European Union regulates only one form of atypical employment, namely part-time work. Directive 1997/81/EC (supplemented by Council Directive 98/23/ EC) aims to provide a legal framework for combating discrimination against parttime workers to improve the quality of work, while facilitating the development of part-time work on a voluntary basis. Part-time work has also been used as a tool against unemployment, with the current focus placed on youth unemployment. Directives were adopted with a specific goal of integrating atypical workers into the labour market and preventing them from facing insecurity by trying to force them into the same position as workers with standard contracts.

Magnani (2003) provides an interesting review how industrial shift in manufacturing, trade and services introduced the use of alternative labour arrangements; how long-term employment contracts and domestic labour markets shifted towards contracting out labour. It should be also interesting to mention the contributions of Ogura (2005), who provides a historic overview of the concept of atypical employment and compares the Anglo-Saxon, European and Japanese models.

Hevenstone (2010) analysed the problem at national level. The complexity of the issue is based on the large variety of definitions. She is writing about part-time work, self-employment, fixed-term contracts, temporary work and freelancing. Lipták (2011) adds to the list mentioned above teleworking, outsourcing and fixed-term labour contracts. Guerrero, Burguillo and Domínguez (2008) ranked part-time job, fixed-term job and temporary work among atypical forms of employment. Havenstone (2011) pointed out that countries with high level of selfemployment have high levels of part-time and fixed-term employment. She also said that a country becomes more prosperous and has higher social protection, if 
there is less self-employment. On the other hand, as the society becomes more prosperous and social security is expands, the level of fixed-term and part-time employment rises, because workers have more willingness to work less and risk periods of unemploy $\neg$ ment between fixed-term contracts. On the other hand, those social benefits provided by employers seem to discourage atypical employment. Finally, the barriers, like strong trade unions and the EPL [employment protection legislation], increase self-employment and fixed-term employment, but discourage part-time work.

In Hungary and in Slovakia the presence of part-time employment is lower compared to the average of $28 \mathrm{EU}$ countries (Figure 1).

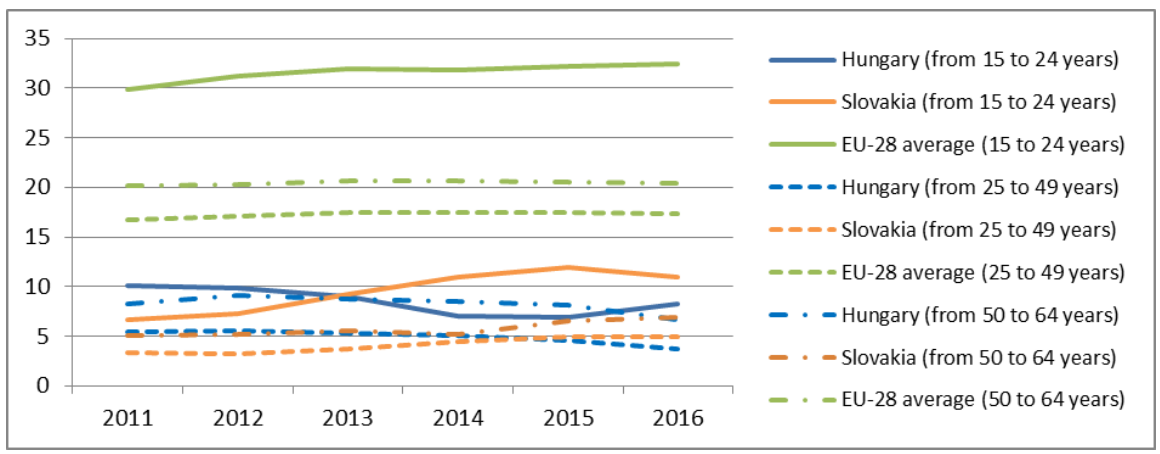

Figure 1

Part-time employment as a percentage of the total employment, by age in Hungary and in Slovakia in 2011-2016 (\%)

Publications focusing on specific problems of different states were published with a focus on employment in Australia, Germany and Great Britain with an emphasis on the social security system (Bieback, 1993). The same perspective in the USA was studied by Stone (2007), in Canada by Robinson (1991), in Spain by Ojea (2009). The emphasis was put on flexibility and security system in the Malaysian private sector by Saad (2001) and labour standards in Ghana (Akorsu and Cooke, 2011). We can mention the contribution of Jana Španková and Tatiana Masárová (2008), who shared their research results about the attitude of employees towards atypical patterns of employment in car industry. Finally, we should mention the study of Poór at al., (2014) about the practices of atypical employment among Slovak and Hungarian employees on the Hungarian-Slovak border.

The researchers are also examining the atypical forms of employment in connection with companies or they consider the issue from different perspectives, e.g. social, political and legal. Some theorists are analysing different forms of atypical employment to make the job market more flexible. The authors are frequently writing about the diversity of atypical employment. 
In our research we focused on unemployed, young people and companies. We are trying to present their attitude towards atypical forms of employment. Fleetwood (2001) discusses the issue from the perspectives of philosophy. $\mathrm{He}$ is trying to demonstrate that deductive method encourages the development of theoretical concepts in such a way that it reduces the multidimensional, qualitative reality of employment and unemployment to the quantitative, single dimension of variables. Addison and Surfield published an article (2009) about the jobless. Those jobless, who choose an atypical form of employment are not only more likely to be employed 1 month and 1 year later than those who continue to search for employment, but also enjoy employment continuity.

The correlation between the atypical forms of employment and companies was researched by most of the scientists. The relation of wage and atypical employment was analysed by Flaschel and Greiner (2011). They pointed out that minimum wage is an important component of flexicurity.

The problem of social security was the issue discussed by Bieback (1993). As we saw at Cordóva (1986), in the late 80's and the early 90's atypical employment was combined with a lower wage and lower living standard as well. As Bieback (1993) said, the most atypical workers were women, so the problem of atypical employment many times is a social problem.

The social approach to atypical employment remains important. In the UK, as one of the most developed countries, Bardasi and Francesconi (2004) conducted a research, how atypical employment influences the wellbeing of the individual. The well being of individual meant to be the mental health, general health condition, life satisfaction and job satisfaction. According to the results of the British Household Panel Survey (1991-2000), the atypical employment does not appear to be associated with adverse health consequences for either men or women, when both health and employment are measured at the same time. Buschoff and Protsch (2008) in a 6-country comparison (Germany, the United Kingdom, the Netherlands, Italy, Denmark, Poland) analysed, how the national social protection policy of individual countries deals with the various forms of non-standard employment patterns, and the specific risks of this policy. They have found significant differences between the policies of the observed countries.

The importance of atypical employment during economic crisis was analysed by Lang, Schömann and Clauwaert (2013). The authors summarized their findings as the following: A two-phase process has been observed during the crisis considering the atypical forms of employment. Employees, who chose atypical pattern of employment, were the first to lose their jobs, as it is easier to get rid of workers not enjoying as much employment protection as standard workers.

In their contribution Ellison and van Berkel (2014) also deal with non-standard forms of employment during an economic crisis. The economic crisis brought increase in unemployment and reduction of social security. Under "atypical" Ellison and Berkel mean "atypical" population groups. The most vulnerable ones 
are the young, migrants and disabled workers. The authors advises to introduce an employee-oriented policy, welfare reforms and austerity measures.

According to Kiss (1997), standard employment is a form of full employment, which means a fixed-time work, social security, defines a social status and equally characteristic for the members of the society, i.e. the busy, hard-working life becomes a unitary pattern (Kiss, 1997).

Frey (2000: 1008) seeks to formulate a definition based on standard features of work. According to her, the traditional standard employment means full-time employment, with an employment contract for an indefinite period, fixed working schedules and working days from Monday to Friday. Atypical employment pattern is considered to be different from this.

Kiss (1997) is disputable when she declares that standard work is characteristic for everyone. It is not even characteristic in the USA, which is still considered to be the most developed country and the homeland of free enterprise. In the 1970s about $85-90 \%$ (Heck, 1995) of the employed worked for wages as employees. Standard work was the norm to be achieved. It is an activity of an adult, who is prepared to get a job after receiving the appropriate qualification.

\section{The Research Objectives and Hypotheses}

The main objective of this research was to explore how atypical forms of employment can help to reduce the unemployment. Flexitime, as a new phenomenon of atypical employment pattern shows a positive impact. It sounds attractive for candidates. The importance and practical part of many theories, which are based on mathematical calculation concerning the labour market, are limited to apply in the reality.

The spread of different forms of employment patterns is influenced by the perception of the public. Our survey is aimed to reveal attitudes towards typical and atypical forms of employment.

- We focused on two areas of interest:

On both sides of the border, and with the help of the (Hungarian and Slovak) Labour Offices, we examined the attitudes and opinion of unemployed towards taking typical or atypical forms of employment. In our research we examined the attitude and opinion of young university and college students studying Economics on adopting typical and atypical forms of employment. In the survey, we also focused on businesses, both sides of the border, following what kind of impact the economic and financial crisis had on their activities, and how did the recovery from the crisis influence their future employment practices.

As similar research was conducted in different countries in the region, we can assume that Central and Eastern European countries reacted similarly on the economic and financial crisis. Based on different criteria (size, form of ownership, 
sector, etc.) the companies provided different HR responses (Fodor, Kiss and Poór, 2010 and 2011). Publications before the crisis clearly highlighted the fact that the employment and HR areas of foreign-owned companies significantly differed from those of domestic companies. The rate of increase in salaries and wages in foreign-owned companies (mainly at management level) exceeded the salary level in locally owned companies.

The research completed in 2014 can be regarded as a second phase of a longer research, as the problem has been analysed from the point of view how nontraditional forms of employment can contribute to the growth of employment. The significant increase in unemployment in 2009 made the issue relevant again, as well as finding new employment opportunities have become an important issue. The results of the previous phase of the research have already been published.

\subsection{Hypotheses of the Research}

The following hypotheses were set up regarding the group of unemployed.

H1.1: The age of the respondents determines their attitude towards the atypical employment patterns.

H1.2: We assume that the respondents of the older generation, as well as the general public will accept the atypical forms of employment involuntarily as a temporary solution.

H1.3: The job seekers believe the adoption of non-standard jobs (or some of them) will reduce the chance for standard jobs.

H1.4: A group of respondents, especially women on maternity leave prefers some atypical forms of work, (part-time and teleworking) and graduates prefer fixedterm contracts).

H1.5: We assume that atypical forms of employment have the lowest preference among the public sector employees.

Younger respondents agreed on the following hypotheses, we aimed to investigate:

H2.1: Age determines the attitude respondents have towards atypical forms of employment.

H2.2: Higher education makes young people more open to atypical forms of employment.

H2.3: Significant differences can be observed between Hungarian and Slovak youth in the evaluation of the acceptance and importance of the atypical forms of employment.

In case of companies we analysed the following hypotheses: 
H3.1: Different sectors are affected in different measure; significant relationship can be assumed between the sectors and the areas affected.

H3.2: The Hungarian and Slovak firms differ significantly in the planned measures related to employment. The outsourcing and the increase of atypical employment patterns are much more characteristic in Slovakia than Hungary.

H3.3: Although atypical forms of employment are known by the majority of companies in Hungary and Slovakia, these are not popular with them, and the companies do not intend to change their standard system of employment.

H3.4: Part-time employment and telecommuting opportunities are used only by a smaller number of companies in both countries, and are more characteristic for foreign companies and joint ventures than the domestic enterprises.

\subsection{Description of the Samples}

The final sample size in the survey was 689 respondents. 294 questionnaires from Slovak respondents and 395 from Hungarians were filled in any significant way. With regard to the location of the respondents the sample had the following territorial distribution: 220 respondents from Esztergom, 175 from Komárom, 91 respondents from Štúrovo and 203 from Komarno. According to the residence of the respondents $65 \%$ lived in cities, while $35 \%$ lived in villages. $51.4 \%$ of the Slovak participants in the study were urban inhabitants, while in Hungary this proportion was much higher, namely $75 \%$ of the respondents indicated city as their place of residence. Analysing the gender composition of the sample, women are almost double incidence. The research included 243 male and 423 female respondents.

Regarding the age structure the under 30 s were about $37 \%$ of the sample, while $25.8 \%$ of respondents were in the age group 30, and $37.2 \% 40$ years of age or older were represented in the survey. Analysing the age structure by country it can be observed that the proportion of responses from the age group under 30 in Slovakia (38.2\%) and Hungary (36\%) was quite similar. In the case of the 30 s age group the proportions differed as follows: in Slovakia it was $22.9 \%$, while in Hungary $28 \%$, followed by people over 40 where there was a similar distribution by country (in the Slovakian sample $38.9 \%$, while in the Hungarian sample $36 \%$ ).

Looking at the marital status of the respondents, $34.3 \%$ of respondents were single and $31.5 \%$ married, $21.2 \%$ lived in a stable relationship, $10.5 \%$ were divorced, while $2.4 \%$ were widowed. The highest proportion, i. e. $34.9 \%$ of the Hungarians in the sample were single. However, among the Slovak respondents the proportion of married and the single people was almost the same (33.6\% and 34.6\%).

$57.5 \%$ of respondents did not have any children, $23.2 \%$, had one child, $13.8 \%$ grew two children, while $5.5 \%$ had 3 or more children. $89.3 \%$ of the participants said that they had no children under three years of age, and nearly $10 \%$ of them 
(9.7\%) grew 1 or 2 foster children under three years old, and $1 \%$ had 3 or more children of this age in the family. In the case of Hungarian respondents without children were represented in the highest proportion $(60.6 \%)$, while the lowest proportion of respondents had 3 or more children (7.6\%). Among the Slovak respondents the still childless were represented in an extremely high proportion (53.4\% of the sample), while the proportion of respondents with 3 or more children was in total $2.7 \%$ of the sample. In both countries, most of the respondents had no children under 3 years (this proportion was in the case of Hungarian respondents $87.7 \%$, while $91.3 \%$ of the Slovaks).

The questionnaire asked about the educational level as a significant factor influencing the chances of obtaining a job. Percentage of subjects with highest level of education was as follows: $25.1 \%$ of them had basic qualifications, in $24.7 \%$ of them had secondary education without maturity, $35.6 \%$ had a high school diploma, while $14.6 \%$ had tertiary qualification. The respondents gave the following answers regarding their most recent jobs or positions.

Table 1

Frequency distribution of unemployed respondents by occupational status

\begin{tabular}{|l|l|l|l|l|}
\hline \multirow{2}{*}{ Occupational status } & \multicolumn{2}{|l|}{ Hungary } & Slovakia \\
\cline { 2 - 5 } & $\begin{array}{l}\text { number of } \\
\text { respondents }\end{array}$ & $\begin{array}{l}\text { percentage } \\
\text { of } \\
\text { respondents }\end{array}$ & $\begin{array}{l}\text { number of } \\
\text { respondents }\end{array}$ & $\begin{array}{l}\text { percentage } \\
\text { of } \\
\text { respondents }\end{array}$ \\
\hline entrepreneur & 14 & 3,54 & 22 & 7,48 \\
\hline lower-level manager & 4 & 1,01 & 12 & 4,08 \\
\hline middle manager & 14 & 3,54 & 5 & 1,70 \\
\hline top manager & 2 & 0,51 & 6 & 2,04 \\
\hline subordinate employee & 159 & 40,25 & 108 & 36,73 \\
\hline skilled worker & 52 & 13,16 & 48 & 16,33 \\
\hline unskilled worker & 53 & 13,42 & 40 & 13,61 \\
\hline $\begin{array}{l}\text { casual worker and } \\
\text { daily wage }\end{array}$ & 26 & 6,58 & 30 & 10,20 \\
\hline public employee & 39 & 9,87 & 8 & 2,72 \\
\hline Valid value & 363 & 91,90 & 279 & 94,90 \\
\hline Missing value & 32 & 8,10 & 15 & 5,10 \\
\hline Total & 395 & 100,00 & 294 & 100,00 \\
\hline
\end{tabular}

Source: Authors' own research

During the research, a total number of 495 questionnaires were handed out. From these were 476 pieces filled in and returned. We were able to evaluate $380-420$, questionnaires depending on the answered questions. Respondents who filled in the questionnaires are 74 men and 128 women from Hungary, 73 men and 128 women from Slovakia. The age structure of respondents is shown in the Table 2. 
Table 2

Frequency distribution of respondents by age

\begin{tabular}{|l|r|r|r|r|}
\hline \multirow{2}{*}{ Age-groups } & \multicolumn{2}{|c|}{ Hungary } & \multicolumn{2}{c|}{ Slovakia } \\
\cline { 2 - 5 } & Frequency & Percentages & Frequency & \multicolumn{1}{c|}{ Percentages } \\
\hline below 19 & 10 & 4,98 & 1 & 0,49 \\
\hline $19-21$ & 56 & 27,86 & 68 & 33,01 \\
\hline $22-24$ & 57 & 28,36 & 85 & 41,26 \\
\hline above 24 & 78 & 38,81 & 52 & 25,24 \\
\hline Total & 201 & 100,00 & 206 & 100,00 \\
\hline
\end{tabular}

Source: Authors' own research

As for marital status, Hungary, $35.14 \%$ of the respondents were single, $13.96 \%$ were married or $59.90 \%$ lived in a stable relationship. In Slovakia, the corresponding proportions were as follows: $56.19 ; 13.40$ and $30.41 \% .88 .08 \%$ of the Hungarian respondents had no children, the number in the case of Slovaks was $90.78 \%$, and 5.70 and $4.85 \%$ of them had one child. While in Hungary $66.27 \%$ of the respondents were full-time tertiary students, the corresponding percentage from the Slovaks was $87.58 \%$. $66.19 \%$ of Hungarian young people participating in the survey work, while for Slovak young people this rate is $69.10 \% .19 .52 \%$ of Hungarian young people and $14.04 \%$ of Slovaks do not work according to their qualifications. With regard to employment patterns, Hungarian young people make the most $(9.9 \%)$ of the normal work (8 hours), $18.62 \%$ in flexible working time, and $13.30 \%$ part-time. Slovak young people tend to undertake 8-hour work in a much smaller proportion than their Hungarian counterparts (11.52\%), 17.28\% in flexible working hours, and $16.23 \%$ in part-time work. The shortened working week is not typical of Hungarian youth, $7.85 \%$ of Slovak young people have chosen this atypical employment form.

Some of 232 companies participated in the survey, 161 from Hungary (69\% of all respondents), while 71 companies from Slovakia (31\%). In terms of the distribution of the sample by ownership, the Hungarian and Slovak companies show a similar picture, $75-75 \%$ of them are in the hands of domestic owners, while $20 \%$ of Hungarians, $14 \%$ of Slovaks (18\% of the total sample) have foreign owners. The proportion of mixed ownership companies among Hungarian companies is $5 \%, 11 \%$ of Slovaks and $7 \%$ of the total sample.

$79 \%$ of the surveyed organizations and companies are private companies, $15 \%$ of them are state- or public owned. In both countries the proportions are very similar in this regard, $81 \%$ of Hungarians, $76 \%$ of Slovaks are private companies in both countries and $15-15 \%$ of organizations / companies are public- or state-owned. Overall, in terms of staff number of companies, $57 \%$ are under $50,16 \%$ between $51-100$ people, $13 \%$ between $100-500$ employees, $7 \%$ between $500-1000$ people and $8 \%$ of the companies employ over 1,000 people. In this area, there is some difference between the two countries. Slovakia represents a higher percentage of companies working with fewer than 100 employees (85\% vs. 67\%), among them 
there is a significant proportion of companies between 50-100 men, which makes $39 \%$ of all Slovak companies. Among the Hungarian companies those firms which employ less than 100 people mostly have less than 50 employees $(62 \%$ of all Hungarian companies). The largest companies employing more than 1000 men are mostly Hungarians, $11 \%$ of Hungarian companies (18 companies), while among the Slovak companies there is just one of these companies (1\%).

The sectorial distribution of firms is very similar in both countries. The maximum rate, a quarter of the total sample, is represented by industrial companies, 26\% among Hungarians, in the Slovaks this ratio is $23 \%$. They are followed by $16 \%$ of trade (14\% of the Hungarians, Slovaks $20 \%$ ). There are no companies which are active in the field of FMCG and telecom companies among the Slovaks, the companies in these two areas is only $2-2 \%$ (that means $4-5$ companies), additional $2-2 \%$ is represented by the areas of energy and education.

\section{$4 \quad$ Analysis of the Results}

Processing and statistical analysis of the data was carried out by IBM SPSS 22.0 for Windows statistical software package. Verification or rejection of the hypothesis is summarized in the Tables 3-5.

Table 3

Summary of Results and Conclusion on the unemployed research

\begin{tabular}{|c|c|c|c|}
\hline Hypothesis & Method & Results & Conclusion \\
\hline $\begin{array}{l}\text { H1.1: Age } \\
\text { determines the } \\
\text { attitudes of the } \\
\text { unemployed } \\
\text { towards atypical } \\
\text { forms }\end{array}$ & $\begin{array}{l}\text { Chi-square } \\
\text { test, } \\
\text { adjusted } \\
\text { standardize } \\
\text { d residuals }\end{array}$ & $\begin{array}{l}\text { Familiarity of atypical forms of } \\
\text { employment by age: Chi-square: } \\
17,197 \text { sign } \mathrm{p}<0,05 \text {. } \\
\text { Accepting employment in atypical } \\
\text { forms of employment by age: } \\
\text { Chi-square: } 23,076 \text { signal } \mathrm{p} \\
<0,001 \text { ). } \\
\text { There was a significant } \\
\text { disagreement by age in the } \\
\text { assessment of atypical forms of } \\
\text { employment such as part-time } \\
\text { employment, seasonal work, labour } \\
\text { leasing, and agent work as future } \\
\text { employment opportunities. }\end{array}$ & justified (true) \\
\hline
\end{tabular}

Table 3

Summary of Results and Conclusion on the unemployed research (continued)

\begin{tabular}{|c|c|c|c|}
\hline Hypothesis & Method & Results & Conclusion \\
\hline $\begin{array}{l}\text { H1.2: We assume } \\
\text { that the } \\
\text { respondents - } \\
\text { especially older } \\
\text { ones - believe for } \\
\text { themselves and } \\
\text { also for others - } \\
\text { that they } \\
\text { themselves and }\end{array}$ & $\begin{array}{l}\text { Chi-square } \\
\text { test, } \\
\text { adjusted } \\
\text { standardized } \\
\text { residuals }\end{array}$ & $\begin{array}{l}\text { In the age-based study, the } \\
\text { majority of respondents evaluate } \\
\text { atypical forms of employment as } \\
\text { a temporary solution, but only in } \\
\text { the case of contract with a labour } \\
\text { leasing company (Chi-square } \\
22,355 \text { sign p <0,05) and in the } \\
\text { case of employment as a leased } \\
\text { worker ( Chi-square : } 24.381\end{array}$ & partially justified \\
\hline
\end{tabular}




\begin{tabular}{|c|c|c|c|}
\hline $\begin{array}{l}\text { people in general } \\
\text { accept the } \\
\text { atypical forms } \\
\text { involuntarily as a } \\
\text { temporary } \\
\text { solution. }\end{array}$ & & $\begin{array}{l}\text { signal } p<0.05 \text { ), statistical } \\
\text { difference can be detected. } \\
\text { Considering the reasons for } \\
\text { acceptance of atypical forms of } \\
\text { employment, only in the case of } \\
\text { casual work (Chi-square: } 32,455 \\
\text { sign p <0,001) and agent work } \\
\text { (Chi-square: } 21,862 \text { sign.: } \\
<0.05) \text {, statistical difference can } \\
\text { be detected between the age } \\
\text { groups. } \\
\text { Considering the reasons for } \\
\text { acceptance of atypical forms of } \\
\text { employment, there is a } \\
\text { significant difference only in the } \\
\text { case of casual work (Chi-square: } \\
32,455 \text { sign p }<0,001 \text { ) and agent } \\
\text { work (Chi-square: } 21,862 \text { sign } p \\
<0,05 \text { ) The choice of casual work } \\
\text { is evaluated as a necessity by all } \\
\text { ages, in the case of agent work } \\
\text { the benefits dominate. }\end{array}$ & \\
\hline $\begin{array}{l}\text { H1.3: Job seekers } \\
\text { consider the } \\
\text { adoption of non- } \\
\text { standard jobs (or } \\
\text { some of them) will } \\
\text { reduce the } \\
\text { chances for a } \\
\text { "normal" position. }\end{array}$ & $\begin{array}{l}\text { Chi-square } \\
\text { test, } \\
\text { adjusted } \\
\text { standardized } \\
\text { residuals }\end{array}$ & $\begin{array}{l}\text { There was a significant } \\
\text { difference between the } \\
\text { respondents of the two countries } \\
\text { regarding the possibility of later } \\
\text { employment. Hungarian } \\
\text { respondents were more likely to } \\
\text { expect increasing future chances, } \\
\text { while the Slovaks expected to } \\
\text { decrease future chances from the } \\
\text { surveyed atypical opportunities. }\end{array}$ & partially justified \\
\hline $\begin{array}{l}\text { H1.4: We assume } \\
\text { that among the } \\
\text { respondents, } \\
\text { especially women, } \\
\text { mothers with } \\
\text { young children } \\
\text { prefer some } \\
\text { atypical forms of } \\
\text { work, (part-time } \\
\text { and teleworking) } \\
\text { and school leavers } \\
\text { (mainly concrete } \\
\text { tasks and fixed- } \\
\text { term contracts). }\end{array}$ & $\begin{array}{l}\text { Independent } \\
\text { Samples T } \\
\text { test }\end{array}$ & $\begin{array}{l}\text { The impact of atypical } \\
\text { employment on the reconciliation } \\
\text { of work and private life. The } \\
\text { opinions of women with and } \\
\text { without children are significantly } \\
\text { different. (T: }-3.974 \text { signal p } \\
<0.001 \text { ). } \\
\text { There is no justifiable difference } \\
\text { between the two groups in the } \\
\text { assessment of the atypical forms } \\
\text { of employment. }\end{array}$ & partially justified \\
\hline $\begin{array}{l}\text { H1.5: We assume } \\
\text { that from the } \\
\text { atypical forms of } \\
\text { employment the } \\
\text { public } \\
\text { employment has } \\
\text { the lowest level of } \\
\text { preference among } \\
\text { employees. }\end{array}$ & $\begin{array}{l}\text { Chi-square } \\
\text { test, } \\
\text { adjusted } \\
\text { standardized } \\
\text { residuals }\end{array}$ & $\begin{array}{l}\text { There was no significant } \\
\text { difference in public employment } \\
\text { between the groups compared. } \\
\text { Nearly half of the respondents } \\
\text { would not accept this form of } \\
\text { employment as a solution. }\end{array}$ & partially justified \\
\hline
\end{tabular}

Source: Authors' own research 
Table 4

Summary of Results and Conclusion on the youth research

\begin{tabular}{|c|c|c|c|}
\hline Hypothesis & Method & Results & Conclusion \\
\hline $\begin{array}{l}\text { H2.1: Age } \\
\text { determines the } \\
\text { attitudes of the } \\
\text { young people } \\
\text { towards atypical } \\
\text { forms }\end{array}$ & $\begin{array}{l}\text { Kruskal } \\
\text { Wallis Test, } \\
\text { Chi-square } \\
\text { test, } \\
\text { adjusted } \\
\text { standardized } \\
\text { residuals }\end{array}$ & $\begin{array}{l}\text { Hungary: younger than } 21 \text { years } \\
\text { are more open to casual, part- } \\
\text { time, and one season work. } \\
\text { Slovakia: younger than } 21 \text { years } \\
\text { refuse public employment and } \\
\text { training organized by the Labor } \\
\text { Centre significantly in higher } \\
\text { proportion. }\end{array}$ & partially justified \\
\hline $\begin{array}{l}\text { H2.2: Higher } \\
\text { education makes } \\
\text { young people } \\
\text { more open to } \\
\text { atypical forms of } \\
\text { employment }\end{array}$ & $\begin{array}{l}\text { Mann- } \\
\text { Whitney U } \\
\text { test }\end{array}$ & $\begin{array}{l}\text { Hungary: young people with } \\
\text { GCSE are more open to casual, } \\
\text { part-time and one season jobs } \\
\text { compared to their counterparts } \\
\text { with tertiary education. } \\
\text { Slovakia: those with a tertiary } \\
\text { education are more open to } \\
\text { public employment compared to } \\
\text { their peers with secondary } \\
\text { education. }\end{array}$ & refused (false) \\
\hline $\begin{array}{l}\text { H2.3: There are } \\
\text { significant } \\
\text { differences } \\
\text { between } \\
\text { Hungarian and } \\
\text { Slovak youth in } \\
\text { the evaluation of } \\
\text { admissibility and } \\
\text { importance of the } \\
\text { atypical forms of } \\
\text { employment }\end{array}$ & $\begin{array}{l}\text { Mann- } \\
\text { Whitney U } \\
\text { test }\end{array}$ & $\begin{array}{l}\text { Willingness to committing } \\
\text { connected with acceptance of } \\
\text { atypical forms of employment: } \\
\text { Slovak students are more mobile } \\
\text { compared to their Hungarian } \\
\text { counterparts. } \\
\text { Atypical foreign employment: } \\
\text { Slovak young people would have } \\
\text { been more likely to have atypical } \\
\text { work abroad than their } \\
\text { Hungarian counterparts. }\end{array}$ & justified \\
\hline
\end{tabular}

Source: Authors' own research

Table 5

Summary of Results and Conclusion on the corporate research

\begin{tabular}{|c|c|c|c|}
\hline Hypothesis & Method & Results & Conclusion \\
\hline $\begin{array}{l}\text { H3.1: The single } \\
\text { types of atypical } \\
\text { forms of } \\
\text { employment vary by } \\
\text { sector. }\end{array}$ & $\begin{array}{l}\text { Chi-square } \\
\text { test, } \\
\text { adjusted } \\
\text { standardized } \\
\text { residuals }\end{array}$ & $\begin{array}{l}\text { Hungary, Slovakia: statistically } \\
\text { significant }(\mathrm{p}<0.01) \text { differences } \\
\text { were identified between the } \\
\text { various sectors in the application } \\
\text { of different atypical forms of } \\
\text { employment. }\end{array}$ & justified (true) \\
\hline $\begin{array}{l}\text { H3.2. The } \\
\text { Hungarian and } \\
\text { Slovak firms differ } \\
\text { significantly from } \\
\text { each other in the } \\
\text { planned measures } \\
\text { related to } \\
\text { employment, of the } \\
\text { Slovaks outsourcing } \\
\text { and the increase of }\end{array}$ & $\begin{array}{l}\text { Mann- } \\
\text { Whitney U } \\
\text { test }\end{array}$ & $\begin{array}{l}\text { Statistically significant }(\mathrm{p}<0.01) \\
\text { differences were identified } \\
\text { between the Hungarian and } \\
\text { Slovakian companies in the } \\
\text { increase in atypical employment. }\end{array}$ & justified (true) \\
\hline
\end{tabular}






\begin{tabular}{|c|c|c|c|}
\hline Hypothesis & Method & Results & Conclusion \\
\hline $\begin{array}{l}\text { H3.3: Although atypical } \\
\text { forms of employment are } \\
\text { known for the majority of } \\
\text { companies in Hungary or } \\
\text { Slovakia, these are not } \\
\text { popular with them, and the } \\
\text { companies do not intend to } \\
\text { change the usual system of } \\
\text { employment. }\end{array}$ & $\begin{array}{l}\text { Mann- } \\
\text { Whitney U } \\
\text { test }\end{array}$ & $\begin{array}{l}\text { There is no significant } \\
\text { difference between the } \\
\text { Hungarian and Slovak } \\
\text { companies in the } \\
\text { attitudes towards } \\
\text { atypical forms of } \\
\text { employment }\end{array}$ & partially justified \\
\hline $\begin{array}{l}\text { H3.4: Part-time employment } \\
\text { and telecommuting } \\
\text { opportunities are used only a } \\
\text { smaller part of companies in } \\
\text { both countries, and are more } \\
\text { characteristic of foreign } \\
\text { companies and joint } \\
\text { ventures, than of the national } \\
\text { ones. }\end{array}$ & $\begin{array}{l}\text { Mann- } \\
\text { Whitney U } \\
\text { test }\end{array}$ & $\begin{array}{l}\text { There is no significant } \\
\text { difference between the } \\
\text { Hungarian and Slovak } \\
\text { companies }(\mathrm{p}=0.345) \text { in } \\
\text { the share of part-time } \\
\text { employees. }\end{array}$ & partially justified \\
\hline
\end{tabular}

Source: Authors' own research

\section{Conclusions}

We had assumed that respondents - particularly the older ones - would believe that "atypical forms of employment were accepted by them (and by others in general) only under compulsion and as a temporary solution". This hypothesis could, in fact, be accepted only in part since the respondents' opinions on opting for atypical ways were inconsistent. Most of the participants in the study basically considered these forms as a possible temporary or transitional form of employment. However, they did not always evaluate these solutions negatively; they even acknowledged the benefits of some. From this perspective, most responses were not age-dependent.

The hypothesis according to which "job-seekers consider at least some atypical ways of employment as diminishing their chances of obtaining a "normal' job" could be regarded as partly justified. Respondents expressed greater aversion to certain forms of atypical employment, such as casual work, public work and telecommuting, in that a relatively high proportion believed that these forms could have a negative effect on their normal opportunities for obtaining work. In addition, it was clear that the responses from the two countries differed significantly on certain atypical types of employment (apart from 'occasional work'). It was also assumed that some respondents (especially women and mothers with small children) prefer some atypical form of work (part-time or telecommuting). Again, this hypothesis could be accepted in part. Among women with a family, atypical forms are believed to be a possible solution for 
coordinating work and private life. They did, however, accept the majority of these forms only as a temporary solution, although having a contract with a labour rental company and telecommuting were thought (by a relatively high proportion) to be an opportunity for longer-term employment.

Finally, it was assumed that of the atypical forms, public-work or public employment has the lowest level of preference among employees. 'Public work' provided a very low preference level according to the respondents, whilst 'utility' was considered above-average in all respects.

Based on the 407 responses to the questionnaire that we received, the main findings can be summarized as follows: On the basis of the results of our research, we can say that age alone does not determine the attitudes of respondents towards atypical forms of employment. There are significant differences between age brackets in respect of some forms of atypical employment, but they often do not match in the two countries. The same age group may have a totally contrary attitude in respect of certain forms of employment in our two countries.

Examining attitudes towards atypical employment among young people, it is clear that only in the case of certain atypical forms of employment can significant disagreement be detected among young people with Secondary or Tertiary Education. Interestingly, the differences shown in the attitudes of Hungarian and Slovak young people do not support each other since the circumstances are quite different. Summarizing the results of the statistical tests, significant differences are visible between Hungarian and Slovak young people in many instances of evaluating and accepting atypical forms of employment. Based on the commuting tendency associated with atypical forms of employment, the occupational mobility of Slovak students is higher than that of their Hungarian counterparts. Highly significant differences can be observed between Hungarian and Slovak young people in atypical employment regarding working abroad: a higher proportion of Slovak youth would agree to atypical forms of work abroad.

We hypothesize that the impact of the recovery from the crisis and of the subsequent growth as this affects corporate employment action, is primarily visible in terms of headcount and increased remuneration in both countries. Both tend to grow most in private enterprises and foreign-owned firms; also, in respect of size, larger companies are more likely to display this than smaller ones. Each area of impact differs by sector and by industry, and in these areas significant relationships can be discerned. Hungarian and Slovak companies differ significantly in the action which they plan in relation to employment: in Slovak companies outsourcing and increasing atypical employment feature much more strongly than in Hungarian. In both countries the measures planned by enterprises concerning employment tend to be more long-term by nature than merely personnel-related solutions. We also see that, although atypical forms of employment are known by the majority of companies, these forms are (neither in Hungary nor in Slovakia) well-liked by business, and the majority of companies 
does not intend to change their customary employment systems. In both countries the option of part-time employment and telecommuting is offered by only a small number of companies and it is more characteristic of foreign companies and joint ventures than of the domestic sector. Two years after the closing of the research, there is a completely new situation in Hungary and Slovakia. Apart from unemployment, there is an increasing problem with labour shortages. Therefore, we are pursuing our research in this direction.

\section{References}

[1] 1.Addison, J. T. \& Surfield, C. J. (2009) Does atypical work help the jobless? Evidence from a CAEAS/CPS cohort Analysis. Applied Economics, 41 (9), 1077-1087

[2] Allmendinger, J., Hipp, L. \& Stuth, S. (2013) Atypical Employment in Europe 1996-2011, Berlin: Wissenschaftszentrum Berlin für Sozialforschung

[3] Antalík, I., Juhász, T., Madarász, I., Poór, J., Szabó, I. \& Tamás, G. (2014) Practices of Atypical Employment among Hungarian and Slovakian Employees in Light of an Empirical Research (In Hungarian) Hungarian Labor Review (Munkaügyi Szemle) 58 (1) 34-44

[4] Akorsu, D. A.\& Cooke, L. F. (2011) Labour Standards Application among Chinese and Indian Firms in Ghana: Typical or Atypical? The International Journal of Human Resource Management, 22 (13) 2730-2748

[5] Aronson, R. L. (1991) Self-Employment. A Labor Market Perspective. New York: Ithaca Press

[6] Bardasi, E. \& Francesconi, M. (2004) The Impact of Atypical Employment on Individual Wellbeing: Evidence from a Panel of British Workers. Social Science \& Medicine, 58 (9) 1671-1688

[7] Bieback, K, J. (1993) Protection of Atypical Work and Family Benefits Comparison of the Australian, German and British Social Security Systems. Policy Studies Review, 12 (1-2) 182-196

[8] Boros Sz. \& Farkas I. (eds.) (2014) Gábor Baross Plan and Regional Development Plan on South Slovakia (In Hungarian) Györ: Association of Hungarian Economists in Slovakia

[9] Casuneanu, I. (2014) Management Priorities to Increase Labor Force Flexibility in the Romanian Organizations. Theoretical and Applied Economics, 21 (4) 143-152

[10] Córdova, E. (1986) From Full-Time Wage Employment to Atypical Employment: A Major Shift in the Evolution of Labour Relations? International Labour Review, 125 (6) 641-657 
[11] Dalminé Kiss G. (1994) Labor and Free-Time. Decline of Labor Paradigmes and Sociology of Free-time (In Hungarian) Hungarian Sociological Review( Szociológia Szemle) (3) 65-79

[12] De Grip, J. \& Hoevenberg, E. W. (1997) Atypical Employment in the European Union. International Labour Review, 136 (1):49-71

[13] Ellison, M. \& van Berkel, R. (2014) Introduction: Innovative Social and Labour Market Policies in Europe in Times of Crisis. International Social Security Review, 67 (2) 1-9

[14] Flaschel, P. \& Greiner, A. (2011) Dual Labor Markets and The Impact of Minimum Wages on Atypical Employment. Metroeconomica, 62 (3):512531

[15] Fleetwood, S. (2001) Conceptualizing Unemployment in a Period of Atypical Employment: A Critical Realist Perspective. Review of Social Economy, 59 (1) 45-69

[16] Fodor P., Kiss T. \& Poór J. (2010) The Impact of the Crisis from the Perspectives of HR and Knowledge Management - Based on Empirical Analysis of Organizations from East European Countries, Organizations, Hungarian Management Scineces (Vezetéstudomány) (10): 2-18

[17] Fodor P., Kiss T. \& Poór J. (2011) Focus on the Impact of the Economic and Financial Crisis on the Human Resource Function - Four Eastern European Countries in the Light of Empirical Research in 2009, Acta Polytechnica Hungarica, Journal of Applied Sciences, (1): 81-104

[18] Frey M. (2000) Flexibility of Working Time Systems, Hungarian Economic Review (Közgazdasági Szemle) 48 (12): 1008-1026

[19] Galasi P. (1997) Labor Market Economy (In Hungarian) Budapest: Aula Publishing House, Budapest

[20] Gialis, S. (2011) Restructuring Strategies, Firms' Size and Atypical Employment in the Local Productive System of Thessaloniki, Greece. Industrial Relations Journal, 42 (5), 412-427

[21] Hardi T. \& Tóth K. (2009) Along our Borders. Socio-economic Analysis of the Slovak-Hungarian Border Area (In Hungarian) Somorja: Fórum Minority Research Institut

[22] Hardi T., Hajdú Z. \& Mezei I. (2009) Borders and Towns in the Carpathian Basin. Győr - Pécs: MTA RKK

[23] Hevenstone, D. (2010) National Context and Atypical Employment. International Sociology, 25 (3): 315-347

[24] Hiltrop, J. M. (1991) Human Resources Practices of Multinational Organizations in Belgium. European Management Journal (4): pp. 404-411 
[25] Horbulák Zs. (2015) Labor Market Comparison of Districts Komárno and Nowe Zamky (In Hungarian) Esztergom and Vidéke (3) 33-39

[26] Kertesi G. \& Köllö J. (2001a) Economic Transformation and the Revaluation of Human Capital - Hungary, 1986-1999 (In Hungarian) Budapest Working Paper, (4)

[27] Kertesi G. \& Köllö J. (2001b) Two Stages of Human Capital and Revaluation of the Economic Transformation (In Hungarian), Hungarian Economic Review (Közgazdasági Szemle) (11) 897-919

[28] Kertesi G. \& Köllő J. (2001c) Sources of Sectorial Wage Differences (Part One) (In Hungarian) Hungarian Labor Review (Munkaügyi Szemle) (7-8) 54-56

[29] Kertesi G. \& Köllö J. (2001d) Sources of Sectorial Wage Differences (Part Two) (In Hungarian) Hungarian Labor Review (Munkaügyi Szemle) (9) 26-28

[30] Kiss G. (1997) Labor and Free-Time. Decline of Labor Paradigmes and Sociology of Free-Time (In Hungarian), In Kiss G. Today's call signals, Sociological Studies, Debrecen:Nullpont Kulturális Egyesület, 9-35

[31] Lang, C., Schömann, I. \& Clauwaert, S. (2013) Atypical Forms of Employment Contracts in Times of Crisis. European Working Paper 03, Brussels

[32] Lengyel I. \& Rechnitzer J. (2004) Regional Economy (In Hungarian), Budapest - Pécs: Dialóg Campus Publishing House

[33] Lipták, K. (2011) Is Atypical Typical? - Atypical Employment in Central Eastern European Countries (1) www.emecon.eu

[34] Magnani, E. (2003) The Productivity Slowdown, Sectoral Reallocations and the Growth of Atypical Employment Arrangements, Journal of Productivity Analysis, 20 (2) 121-142

[35] Moberly, R. B. (1987) Temporary, Part-Time and Other Atypical Employment Relationship in the United States. Labor Law Journal, 38 (11) 689-696

[36] Ogura, K. (2005) International Comparison of Atypical Employment Differing Concepts and Realities in Industrialized Countries. Japan Labour Review, 2 (2) 5-29

[37] Oliveira, L., Carvalho, L.\& Veloso, H. (2011) Formas atípicas de emprego juvenil na uniãoeuropeia. Sociologia, problemas e práticas (66) 27-48

[38] Pérez G., L.,Castellano B., E. \& Pérez D., F. (2008). Trabajo atípico en la Unión Europea. Revista Gaceta Laboral, 14 (3) 327-350

[39] Poór J., Kosár Sz., Fodor P.,Tóth V., Majó Z., Csiba Zs. \& Huszárik E. (2012) The Impact of the Crisis and Recovery on HR and Knowledge 
Management in Focus - a Hungarian-Slovakian Comparison 2009 Periodica Polytechnica Social and Management Sciences (1) 29-44

[40] Robinson, O. (1991) Atypical Workforce: Raising the Status of Part-Time Employment - Canada, Industrial Relations Journal, 22 (1) 46-58

[41] Saad, H. S. (2011) Regulating Atypical Employment in The Malaysian Private Sector: Balancing Flexibility and Security. Journal of Global Management, 3 (1) 59-73

[42] Schulze B., K.\& Protsch, P. (2008) (A-)typical and (in-)secure? Social protection and "non-standard" forms of employment in Europe. International Social Security Review, 61 (4) 51-73

[43] Španková, J. \& Masárová, T. (2008) Flexibilné formy pracovnoprávnych vzt'ahov v podnikoch automobilového priemyslu. Economic and Social Policy of EU III. International conference, Senec May 22

[44] Stone, K. V. W. (2007) Legal Protections for Atypical Employees: Employment Law for Workers without Workplaces and Employees without Employers. Berkeley Journal of Employment and Labor Law, 27 (2):251286

[45] Stone, K. V. W. (2007) Legal Protections for Atypical Employees: Employment Law for Workers without Workplaces and Employees without Employers. Berkeley Journal of Employment and Labor Law. 27 (2) 251286

[46] Szüdi, G. \& Kováčová, J. (2014) Towards Greater Flexibility And More Jobs? - Comparison of Recent Changes in Labour Market Regulation in The Visegrad Countries. International scientific conference Determinants of Flexibilization of Work in the View of Family And its Implementations into Social System of Slovak Republic, Banská Bystrica: March 25 ${ }^{\text {th }} 2014$

[47] Trillo O, M. (2009) Los contratos temporales y a tiempo parcial como formas de trabajo atípicas. Especial referencia a su régimen de seguridad social. Revista Gaceta Laboral, 15 (1) 101-130 